\title{
KAJIAN POTENSI PENGGUNA KERETA API PADA JALUR REAKTIVASI CIBATU - GARUT
}

\author{
Rianto Rili Prihatmantyo, M.Sc \\ Dosen STTD \\ Jl. Raya Setu No. 89, Bekasi \\ Telp./Fax : (021) 8254640
}

Drs. Fauzi, MT

Dosen STTD

J1. Raya Setu No. 89, Bekasi

Telp./Fax : (021) 8254640

\author{
Utut Widyanto, M.Sc \\ Dosen STTD \\ Jl. Raya Setu No. 89, Bekasi \\ Telp./Fax : (021) 8254640
}

Rachmat Sadili, MT

Dosen STTD

Jl. Raya Setu No. 89, Bekasi

Telp./Fax : (021) 8254640

\begin{abstract}
Government plan in the railway reactivation in Jawa Barat Province, there are 4 railways which one of them is Cibatu - Garut-Cikajang line along 47,5 km. In 2019, prioritaized to reactivate Cibatu - Garut line along 19,3 km. The goal in this research is to review the modal shift potential from other transportation modes to railway on Cibatu - Garut line. The method used in this reasearch is stated preference method. From the modal shift potential analysis result, with present tariff condition approximately $31 \%$ of respondents willing to shift to using railway mode if it operated. But if the tariff lower as Rp. 40.000,then the potential modal shift increasing to $60 \%$. In other condition, if the headway between railways become every 6 hrs/day or about 4 trips per day, then the potential modal shift is also can reach $60 \%$.
\end{abstract}

Keywords: Reaktivation, Stated Prefernce, Modal Shift

\section{ABSTRAKSI}

Rencana pemerintah dalam reaktifasi jalur kereta api di wilayah Provinsi Jawa Barat ada 4 jalur kereta api, salah satunya rute Cibatu - Garut - Cikajang sepanjang 47,5 km. Pada tahun 2019 diprioritaskan untuk mengaktifasi jalur Cibatu - Garut sepanjang 19,3 km. Tujuan penelitian ini adalah mengkaji potensi 
perpindahan pengguna moda angkutan lain ke angkutan kereta api lintas Cibatu Garut. Metode yang digunakan dalam penelitian ini adalah metode stated preference. Dari hasil analisis potensi perpindahan moda, untuk kondisi tarif saat ini kurang lebih $31 \%$ responden yang bersedia pindah ke angkutan kereta api jika jalur reaktifasi beroperasi. Jika tarif menjadi lebih rendah yaituRp. 40.000,potensi perpindahan moda dapat mencapai 60\%. Jika headway moda menjadi 6 jam/hari atau sekitar 4 perjalanan tiap hari, maka potensi perpindahan moda dapat mencapai $60 \%$.

\section{Kata Kunci : Reaktifasi, Stated Preference, Perpindahan Moda}

\section{PENDAHULUAN}

\section{A. LATAR BELAKANG PENELITIAN}

Saat ini pemerintah sedang mengkaji perlunya membuka kembali (reaktifasi) jalur kereta api yang tidak aktif atau tidak beroperasi sejak lama di beberapa jalur kereta api di Pulau Jawa dan Sumatra. Salah satu rencana reaktifasi jalur kereta api adalah di Daerah Operasi 2 (Daop 2) Bandung, Provinsi Jawa Barat yang direncanakan 4 jalur kereta api. Adapun empat jalur kereta api yang akan direaktifasi adalah rute Cibatu - Garut - Cikajang sepanjang 47,5 km; rute Rancaekek - Tanjungsari sepanjang 11,5 km; rute Banjar - Pangandaran Cijulang sepanjang $82 \mathrm{~km}$; dan rute Bandung - Ciwidey sepanjang 37,8 km.Namun pada tahun 2019 diprioritaskan untuk mengaktifasi jalur Cibatu Garut sepanjang 19,3 km, sedangkan untuk ketiga jalur lainnya direncanakan selesai dalam tiga tahun ke depan. 


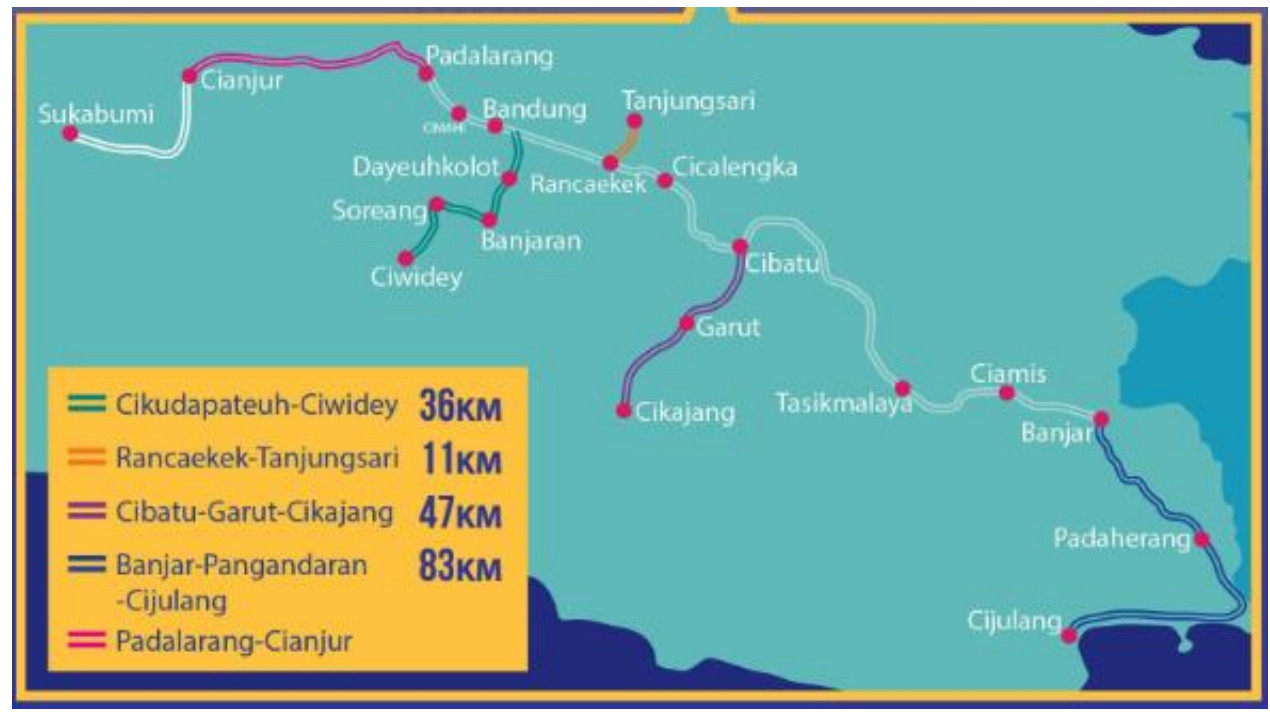

Gambar 1Rencana Jalur Reaktifasi Provinsi Jawa Barat

Adapun untuk saat ini pembangunan jalur reaktivasi Cibatu - Garut telah mencapai 90\% dan direncanakan dapat beroperasi pada bulan Oktober.Data jumlah penumpang naik dan turun di Stasiun Cibatu pada tahun 2018 didapatkan rata-rata sebanyak 20.700 penumpang tiap bulan.Sebanyak 50\% melanjutkan perjalanan ke Kabupaten Garut menggunakan kendaraan pribadi, angkutan umum maupun dengan transportasi daring. Selain itu, jumlah penumpang naik dan turun di Terminal Guntur, Kabupaten Garut pada bulan Juli 2019 mencapai 125.835 penumpang atau sekitar 4.200 per hari.

Untuk perjalanan orang dari wilayah Kabupaten Garut ke wilayah Jakarta dan sekitarnya menggunakan angkutan umum saat ini tersedia bus Angkutan Kota Antar Provinsi atau travel. Sementara jika menggunakan kereta api dapat naik dari Stasiun Cibatu langsung menuju Jakarta atau dari Stasiun Cibatu menuju Stasiun Bandung terlebih dahulu dilanjutkan menuju Jakarta dengan kereta yang berbeda.Dengan adanya jalur reaktivasi nanti, perjalanan orang dari Kabupaten Garut menggunakan kereta api dapat langsung menuju Jakarta.

\section{B. RUMUSAN MASALAH}

Berdasarkan latar belakang yang telah dijelaskan bahwa dapat disimpulkan beberapa permasalahan yaitu:

1. Bagaimana kondisi eksisting di Stasiun Cibatu dan Stasiun Garut? 
2. Bagaimana karakteristik calon pengguna angkutan kereta api lintas Cibatu - Garut?

3. Berapa potensi perpindahan pengguna moda angkutan lain ke angkutan kereta api lintas Cibatu - Garut?

\section{TUJUAN PENELITIAN}

Berdasarkan rumusan masalah tersebut, maka tujuan dari penelitian ini adalah sebagai berikut:

1. Mengidentifikasi kondisi eksisting di Stasiun Cibatu dan Stasiun Garut;

2. Menganalisis karakteristik calon pengguna angkutan kereta api lintas Cibatu - Garut;

3. Menganalisis potensi perpindahan pengguna moda angkutan lain ke angkutan kereta api lintas Cibatu - Garut.

\section{METODOLOGI PENELITIAN}

Adapun analisis yang digunakan dalam penelitian ini adalah :

1. Analisis Karakteristik Sosio-ekonomi

2. Metode Stated Preference

3. Analisis Logit Binomial

\section{HASIL ANALISIS}

\section{A. KONDISI STASIUN CIBATU DAN STASIUN GARUT}

Stasiun Cibatu(CB) terletak pada ketinggian +612 meter ini merupakan stasiun kereta api aktif terbesar di Kabupaten Garut dan termasuk dalam Daerah Operasi (DAOP) 2 Bandung. Lokasi stasiun ini kurang lebih 21 kilometer di sebelah utara pusat kota Kabupaten Garut. Posisi dan ukuran stasiun yang relatif besar ini menjadikan stasiun ini menjadi stasiun utama keberangkatan bagi warga Garut untuk bepergian ke berbagai jurusan di Jawa dengan kereta api.Berdasarkan hasil survei inventarisasi yang telah dilaksanakan, dengan cara membandingkan kondisi eksisting dengan PM No. 29 Tahun 2011 tersebut, sebagian besar fasilitas sudah ada dan dalam kondisi yang sudah baik (Tabel 1).

Berdasarkan Tabel 1 tersebut, fasilitas utama untuk kegiatan pokok yang ada di stasiun Cibatu saat ini sudah baik, kurang lebih $80 \%$ dari seluruh fasilitas yang seharusnya ada dan kondisi masih cukup baik. Untuk fasilitas yang 
belum ada di Stasiun Cibatu ini adalah tidak adanya fasilitas untuk penyandang cacat dan lansia, serta ruang fasilitas kesehatan.

Selain fasilitas untuk kegiatan pokok, Stasiun Cibatu harus menyediakan fasilitas kegiatan penunjang dan kegiatan jasa pelayanan khusus.Namun, untuk fasilitas - fasilitas tersebut masih sangat kurang. Untuk fasilitas kegiatan penunjang yang sudah ada di Stasiun Cibatu adalah fasilitas perparkiran dengan kondisi hanya berupa lapangan parkir yang belum diatur atau dikelola dengan baik.

Tabel 1 Fasilitas Kegiatan Pokok di Stasiun Cibatu

\begin{tabular}{|l|l|c|c|}
\hline \multicolumn{2}{|c|}{ Kegiatan Pokok } & Ketersediaan & Kondisi \\
\hline No & \multicolumn{1}{|c|}{ Ada } & Baik \\
\hline 1. & Hall & Ada & Baik \\
\hline 2. & Perkantoran Kegiatan Stasiun & Ada & Baik \\
\hline 3. & Loket Karcis & Ada & Baik \\
\hline 4. & Ruang Tunggu & Ada & Baik \\
\hline 5. & Ruang Informasi & Ada & Baik \\
\hline 6. & Ruang Fasilitas Umum & Ada & Baik \\
\hline 7. & Ruang Fasilitas Keselamatan & Ada & Baik \\
\hline 8. & Ruang Fasilitas Keamanan & Tidak ada & \\
\hline 9. & Ruang Fasilitas penyandang cacat dan lansia & Tidak ada & \\
\hline 10. & Ruang Fasilitas Kesehatan & & \\
\hline
\end{tabular}

Untuk kegiatan operasi kereta api naik turun penumpang, emplasemen di Stasiun Cibatu terdapat 4 jalur dengan satu peron tepi dan 2 peron pulau. Selain itu, dari 4 jalur tersebut, 2 jalur sebagai sepur lurus dengan peron yang rendah sehingga membutuhkan bantuan bancik atau tangga kecil untuk memudahkan dan memberi kenyamanan penumpang untuk keperluan naik turun kereta.

Sementara Stasiun Garut (GRT) merupakan stasiun kereta api non-aktif kelas II yang terletak di Pakuwon Garut Kota, Kabupaten Garut. Stasiun yang terletak pada ketinggian +717 meter. Karena stasiun ini sudah tidak beroperasi, maka kondisi infrastruktur baik di dalam stasiun maupun di luar stasiun rusak. Dengan adanya rencana reaktivasi jalur lintas Cibatu - Garut otomatis Stasiun Garut harus direnovasi total untuk mendukung kegiatan naik turun penumpang kereta api nantinya. Sampai bulan Juli sudah selesai proses pengosongan wilayah stasiun dan seluruh jalur lintas Cibatu - Garut, 
sedangkan untuk perbaikan jalur lintas sudah mencapai $90 \%$ atau kurang lebih $4 \mathrm{~km}$.

Saat ini terdapat 32 perjalanan kereta yang melewati Stasiun Cibatu ini, 14 perjalanan diantaranya berhenti di Stasiun Cibatu dan 18 lainnya hanya melintas langsung.Jumlah penumpang naik rata-rata dari Stasiun Cibatu menuju wilayah Jabodetabek dan wilayah di Jawa Barat dari tahun 2016 sampai dengan 2018 mengalami peningkatan mencapai 100\%, dari 9.783 orang menjadi 19.675 orang. Sementara untuk jumlah penumpang turun mengalami peningkatan sekitar 50\%, dari 18.818 orang di tahun 2016 menjadi 27.202 orang di tahun 2018.Grafik jumlah penumpang rata-rata naik dan turun dari dan ke Stasiun Cibatu pada tahun 2016 sampai dengan tahun 2018 dapat dilihat pada Gambar 2.

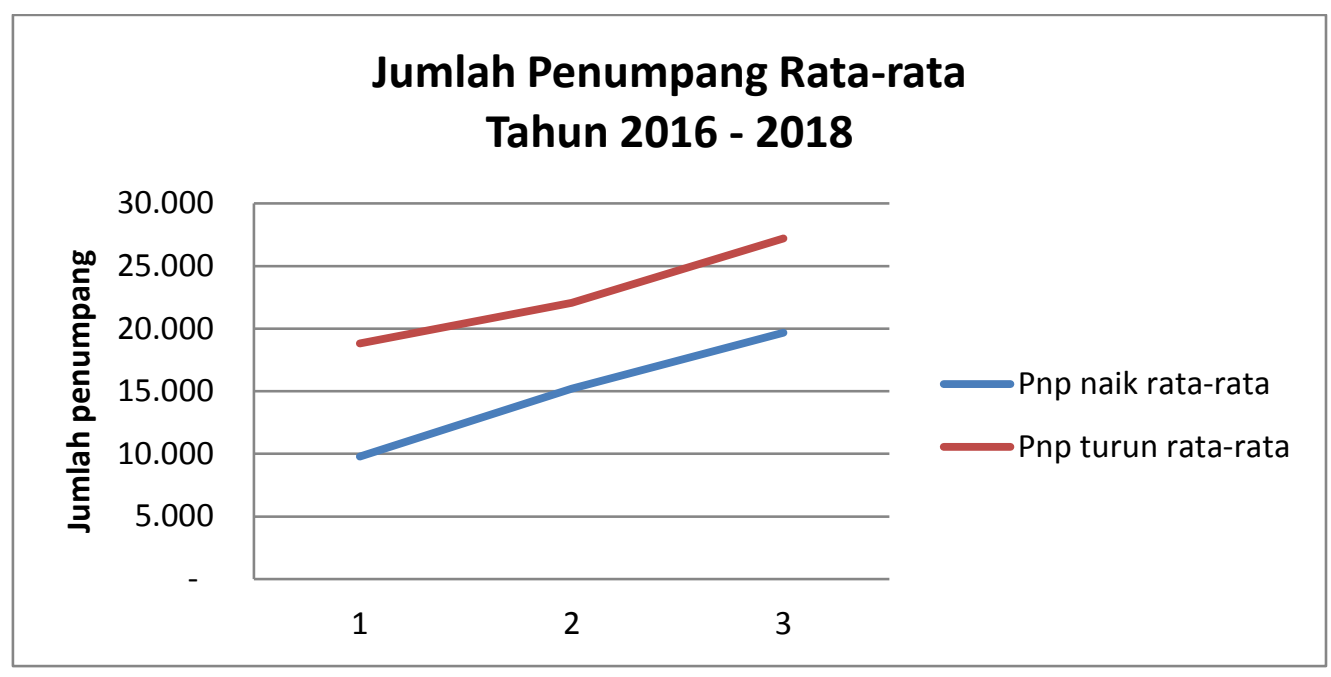

\section{Gambar 2 Jumlah Penumpang Naik Turun di Stasiun Cibatu}

Tahun 2016-2018

\section{B. KARAKTERISTIK PENUMPANG BUS DI TERMINAL GUNTUR GARUT}

Untuk mendapatkan karakteristik sosio-ekonomi dari pengguna angkutan umum di Kabupaten Garut, berdasarkan survei wawancara menggunakan formulir kuesioner di Terminal Guntur Garut. Jumlah responden yang dapat dilakukan survei berdasarkan jumlah naik dan turun penumpang di Terminal 
Guntur dan dari hasil perhitungan sampel didapatkan sebanyak 250 responden.

1. Karakteristik JenisKelamin Penumpang

Prosentase terbesar berdasarkan jeniskelaminpenumpang turunnaik di Terminal Guntur Garut adalah laki-laki dengan prosentase sebesar 69\%sebanyak 173 responden, sedangkan prosentase jeniskelaminwanitadengan prosentase sebesar 31\%sebanyak 77 responden.

2. Karakteristik Pendidikan Penumpang

Prosentase terbesar responden dilihat dari tingkat pendidikan penumpang naik dan turun di Terminal Guntur Garut adalah tingkat SLTA dengan prosentase sebesar 53\%sebanyak 132 responden, sedangkan prosentase terkeciladalah tingkat SD dengan prosentase sebesar 7\%dengan jumlah responden sebanyak 17.

3. Karakteristik Pekerjaan Penumpang

Prosentase terbesar pekerjaanpenumpang turundan naik di Terminal Guntur Garut adalah pekerjaanwiraswasta dengan prosentase sebesar 33\%sebanyak 132 responden, sedangkan prosentaseterkecildengan pekerjaan PNS/TNI/POLRI dengan prosentase sebesar 7\% sebanyak 17 responden.

4. Karakteristik MaksudPerjalanan Penumpang

Prosentase terbesar MaksudPerjalananpenumpang turun dannaik di Terminal Guntur Garut adalah bekerja/bisnis dengan prosentase sebesar 57\% sebanyak 168 responden, sedangkan prosentase sekolah/kuliah dan lainnya dengan prosentase sebesar 3\%sebanyak 9 responden.

5. Karakteristik Penghasilan Penumpang

prosentase terbesar Penghasilanpenumpang turundan naik di terminal Guntur GarutsebesarRp 2 Juta sampai denganRp 5 Jutadengan prosentase sebesar 53\%sebanyak 133 responden, sedangkan prosentase terkeciladalahpenghasilan lebih dari Rp 10Juta dengan prosentase sebesar $2 \%$ sebanyak 6 responden.

6. Karakteristik PengeluaranTransportasi Per Bulan 
Prosentase terbesar PengeluaranTransportasi Per Bulanpenumpang turundan naik di Terminal Guntur Garutsebesarkurang dari Rp. 250 ribu dengan prosentase sebesar 59\%sebanyak 148 responden, sedangkan prosentase terkecillebih dariRp. 1 jutadengan prosentase sebesar $1 \%$ sebanyak 2 responden.

\section{ANALISIS PERPINDAHAN PENGGUNA MODA ANGKUTAN LAIN KE ANGKUTAN KERETA API}

1. Pelayanan Angkutan Umum Di Kabupaten Garut Saat ini masyarakat di wilayah Kabupaten Garut yang akan melakukan perjalanan menuju ke wilayah Jakarta dan sekitarnya mempunyai dua alternatif moda angkutan, yaitu menggunakan bus dan kereta api. Penggunaan moda kereta api jika penumpang akan menuju wilayah Garut harus terlebih dahulu melakukan perjalanan menuju stasiun terdekat yaitu Stasiun Cibatu. Dari Stasiun Cibatu baru dilanjutkan dengan kereta api tujuan Jakarta yang hanya dilayani oleh dua kereta, yaitu Kereta Serayu dan Kereta Pangandaran. Dua kereta ini hanya berhenti di Stasiun Cibatu 1 kali dalam 1 hari.

Selain menggunakan moda kereta api, masyarakat Kabupaten Garut dapat menggunakan moda bus untuk perjalanan ke wilayah Jakarta dan sekitarnya, dilayani oleh 15 (lima belas) bus baik yang berupa AKDP (Angkutan Kota Dalam Provinsi) maupun AKAP (Angkutan Kota Antar Provinsi). Semua pelayanan angkutan jalan berawal di Terminal Guntur Kabupaten Garut yang merupakan terminal Tipe A, yang saat ini terminal Guntur dikelola oleh Direktorat Jenderal Perhubungan Darat Kementerian Perhubungan.Jarak Terminal Garut menuju Stasiun Garut cukup dekat yaitu kurang lebih $2 \mathrm{Km}$, namun melalui ruas jalan dengan tata guna lahan sebagian besar daerah komersial, sehingga lalu lintas cukup ramai.Waktu tempuh jika menggunakan kendaraan pribadi kurang lebih 10 menit.

Untuk angkutan perkotaan yang ada di Kabupaten Garut sebanyak 16 trayek, namun hanya 5 trayek yang melalui daerah stasiun tepatnya melewati ruas Jalan Pramuka yang berada di bagian barat stasiun dan 
bersinggungan langsung dengan jalan stasiun, dengan jarak kurang dari 500 meter.Waktu tempuh setiap angkutan perkotaan yang melalui Jalan Pramuka menuju stasiun dibutuhkan waktu sebanyak 10 menit. Dengan headway rata-rata angkutan perkotaan di Kabupaten Garut sebesar 15 menit,sehingga alternatif angkutan perkotaan terusan dari Stasiun Garut cukup banyak untuk menuju Terminal Guntur.

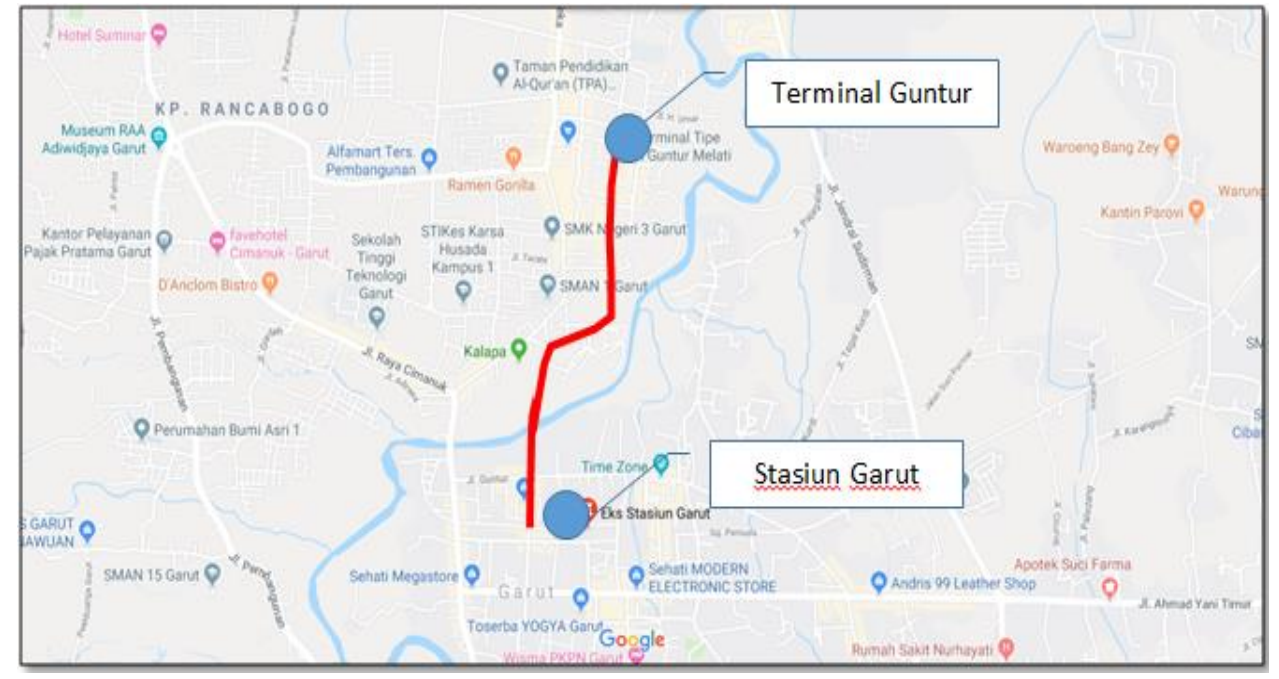

Gambar 3 Peta Lintasan Angkutan Perkotaan Ke Stasiun Garut

2. Potensi Perpindahan Pengguna Moda Angkutan Umum

Untuk mengetahui potensi pengguna moda angkutan umum dalam penelitian ini menggunakan metode stated preference dan dilanjutkan dengan menggunakan analisis Logit. Tujuan utama analisis data Stated Preference ini adalah untuk mengestimasi probabilitas seseorang memilih moda KA dibandingkan dengan moda bus yang biasa digunakannya pada rute perjalanan yang ditinjau.Perkiraan sebaran penumpang dari dan menuju Stasiun Garut adalah berdasarkan pola sebaran penumpang moda lain di Terminal Guntur. Karena pada saat ini pelayanan transportasi jalan dari dan menujuKabupaten Garut hanya dilayani oleh AKAP.Sehingga survei sebaran penumpang dapat berdasarkan sebaran penumpang bis. Pada penelitian ini potensi penumpang yang berpindah moda ke kereta api dibandingkan berdasarkan tarif dan headway moda.

a. Perhitungan Regresi Logistik Berdasarkan Tarif 
Pada penelitian ini, moda yang dibandingkan adalah moda bus dan kereta api dengan tujuan Cibatu atau Garut. Dengan analisis regresi logistik berdasarkan tarif didapatkan hasil seperti dalam Tabel 2.

Tabel 2 Perhitungan Probabilitas Modal Shift Berdasarkan Tarif Bus Yang Dikenakan

\begin{tabular}{|c|c|r|c|c|c|}
\hline $\begin{array}{c}\text { Tarif }(\mathrm{Rp} \\
\text { Dalam ribuan })\end{array}$ & $\mathrm{y}$ & $\mathrm{p}$ & $\mathrm{LL}$ & & $\mathrm{B}$ \\
\hline 20 & 0,759 & 0,837449 & $-30,8911$ & & \\
\hline 30 & 0,821 & 0,736908 & $-32,8141$ & Bo & 2,858173 \\
\hline 40 & 0,688 & 0,603616 & $-20,3597$ & $\mathrm{Bi}$ & $-0,06094$ \\
\hline 50 & 0,357 & 0,452928 & $-37,5547$ & & \\
\hline 60 & 0,341 & 0,3104 & $-26,4129$ & & \\
\hline & & & $-148,032$ & & \\
\hline
\end{tabular}

Untukpersamaan utilitas berdasarkan Tabel 2 didapatkan persamaan sebagai berikut:

$\mathrm{U}_{\mathrm{KA}}-\mathrm{U}_{\mathrm{BUS}}=2,858-0,06 \mathrm{X}_{1}$

Jadi jika tarif yang direncanakan kurang lebih sama dengan tarif saat ini (untuk lintas Cibatu - Jakarta) yaitu Rp. 60.000,- maka potensi penumpang yang berpindah dari bus ke kereta api sebesar $31 \%$. Sedangkan jika tarif menjadi lebih rendah yaitu Rp.40.000,- maka potensi penumpang yang berpindah menjadi $60 \%$.

b. Perhitungan Regresi Logistik Berdasarkan Headway Moda Dari data sekunder yang didapat, diketahui bahwa moda kereta api memiliki headway 2 moda per hari sedangkan moda bus memiliki headway 1 jam sekali untuk perharinya.Dengan analisis regresi logistik berdasarkan headway moda didapatkan hasil seperti dalam Tabel 3.

Tabel 3 Perhitungan Probabilitas Modal Shift Berdasarkan Headway Moda Kereta Api

\begin{tabular}{|c|r|r|r|l|r|}
\hline Headway Moda & \multicolumn{1}{c|}{$\mathrm{y}$} & \multicolumn{1}{c|}{$\mathrm{p}$} & \multicolumn{1}{c|}{ LL } & & \multicolumn{1}{c|}{$\mathrm{B}$} \\
\hline 2 jam/hari & 0,759259 & 0,837445 & $-30,891$ & & \\
\hline 4 jam/hari & 0,820896 & 0,736903 & $-32,8142$ & Bo & 2,248739 \\
\hline 6 jam/hari & 0,6875 & 0,60361 & $-20,3598$ & Bi & $-0,3047$ \\
\hline
\end{tabular}




\begin{tabular}{|c|l|l|l|l|l|}
\hline 8 jam/hari & 0,357143 & 0,452922 & $-37,5546$ & & \\
\hline 10 jam/hari & 0,341463 & 0,310395 & $-26,4129$ & & \\
\hline & & & $-148,032$ & & \\
\hline
\end{tabular}

Untukpersamaan utilitas berdasarkan Tabel 3didapatkan persamaan sebagai berikut:

$$
\mathrm{U}_{\mathrm{KA}}-\mathrm{U}_{\mathrm{BUS}}=2,248-0,305 \mathrm{X}_{2}
$$

Jadi jika headway yang direncanakan yaitu 10 jam/hari atau 2 perjalanan kereta api yang melayani dalam satu hari (sama dengan saat ini),- maka potensi penumpang yang berpindah dari bus ke kereta api sebesar 31\%. Sedangkan jika lintas Garut - Jakarta dilayani dengan headway 6 jam/hari atau sekitar 4 perjalanan kereta api setiap hari,- maka potensi penumpang yang berpindah mencapai $60 \%$.

3. Analisis Integrasi Moda di Satsiun Garut

Moda transportasi yang melayani perjalanan jarak jauh sebagian besar tidak melayani "door to door services", sehingga perlu dukungan dari pelayanan lain yang harus memiliki standar pelayanan yang setara. Termasuk di Stasiun Cibatu, sampai saat ini tidak ada pelayanan angkutan resmimenuju stasiun dan dari stasiunsehingga permintaan penumpang akan layanan perkeretaapian di Stasiun Cibatu masih rendah.Dalam rencana reaktivasi Stasiun Garut, maka pemerintah daerah Kabupaten Garut harus mempersiapkan pelayanan apa yang akan diberikan kepada penumpang kereta api yang turun dan naik di Stasiun Garut.Berikut rekomendasi yang dapat dilakukan untuk peningkatan kenyamanan dan kemudahan perpindahan moda di Stasiun Garut:

a. Pembangunan fasilitas naik turun penumpang angkutan perkotaan berupa halte di depan Stasiun Garut.

b. Pembangunan fasilitas pejalan kaki dari stasiun menuju halte angkutan perkotaan yang memberikan perlindungan dari cuaca.

c. Melengkapi petunjuk dan informasi alur perpindahan.

d. Melakukan review jaringan trayek angkutan perkotaan akibat adanya reaktivasi Stasiun Garut.

e. Melengkapi fasilitas perpindahan bagi kaum diffable. 
f. Sosialisasi rute trayek dan jadwal pelayanan angkutan jalan yang tersedia di Terminal Guntur kepada penumpang.

\section{KESIMPULAN}

1. Fasilitas kegiatan pokok untuk keperluan naik dan turun penumpang di Stasiun Cibatu saat ini sudah cukup lengkap, tetapi perlu ditambahkan untuk fasilitas penunjang seperti peron yang masih rendah serta fasilitas parkir yang belum memadai. Sedangkan di Stasiun Garut saat ini masih dalam tahap renovasi dan penambahan fasilitas, baik fasilitas pokok maupun fasilitas penunjang lainnya.

2. Dilihat dari karakteristik sosio-ekonomi pengguna angkutan umum di wilayah Kabupaten Garut, sebanyak 67\% pengguna bus melakukan perjalanan untuk bekerja yang didominasi oleh pegawai swasta dan wiraswasta. Selain itu, rata-rata pengeluaran tiap bulan untuk transportasi sebanyak 59\% berkisar sampai dengan Rp. 250.000,-.

3. Hasil analisis stated preference antara moda bus dan kereta api jika jalur reaktivasi Cibatu - Garut beroperasi didapat persamaan utilitas berdasarkan tarif $\mathrm{UKA}_{\mathrm{KA}}-\mathrm{U}_{\mathrm{BUS}}=2,858-0,06 \mathrm{X}_{1}$ dan persamaan utilitas berdasarkan headway moda $\mathrm{U}_{\mathrm{KA}}-\mathrm{U}$ BUS $=2,248-0,305 \mathrm{X}_{2}$.

4. Potensi perpindahan moda angkutan umum lain berpindah menggunakan moda angkutan kereta api menuju ke arah Jakarta dan sekitarnya, jika jalur reaktivasi Cibatu - Garut telah selesai dengan asumsi tarif yang harus dikeluarkan sama dengan saat ini yaitu kurang lebih sebesar $31 \%$. Jika tarif menjadi lebih rendah yaitu Rp.40.000,- maka potensi penumpang yang berpindah menjadi $60 \%$. Selain itu, jika headway moda juga sama dengan saat ini (10 jam/hari atau 2 perjalanan tiap hari) yaitu sebesar 31\%. Jika lintas Garut - Jakarta dilayani dengan headway 6 jam/hari atau sekitar 4 perjalanan kereta api setiap hari,- maka potensi penumpang yang berpindah mencapai $60 \%$.

\section{E. SARAN}

1. Perlu penyesuaian terhadap harga tiket dan frekuensi perjalanan kereta api sehingga dapat meningkatkan probabilitas perpindahan moda menggunakan kereta api di Stasiun Cibatu dan Stasiun Garut. 
2. Perlu dilakukan penelitian lebih lanjut untuk pelayanan angkutan kota yang melayani penumpang dari Stasiun Garut.

3. Perlu dilakukan penelitian lebih lanjut terkait rencana pengoperasian kereta api nantinya.

\section{DAFTAR PUSTAKA}

Agustin dkk, (2006), Analisis Variabel Layanan Angkutan Umum Bus Kota Menurut Persepsi Penumpang Dengan Teknik Stated Preference (Studi Kasus Angkutan Umum Bus Kota di Surakarta), Universitas Sebelas Maret, Surakarta

Daerah Operasi 2, (2019), Daftar Nama Kereta dan Jadwal Kedatangan di Satsiun Cibatu, PT. Kereta Api Indonesia, Bandung

Kantor Terminal Guntur, (2019), Data Jumlah Naik Turun Penumpang di Terminal Guntur Garut Bulan Juli 2019, Dinas Perhubungan Kabupaten Garut, Kabupaten Garut

Kementerian Perhubungan, (2011), Peraturan Menteri No. 29 Tahun 2011 Tentang Persyaratan Teknis Bangunan Stasiun Kereta Api

Satrio dkk, (2014), Kajian Potensi Penumpang Angkutan Kereta Api Lintas Madura (Bangkalan - Sumenep PP) Dengan Menggunakan Metode Stated Prefrence, Universitas Brawijaya, Malang

Tamin, O.Z., (2000), Perencanaan dan Permodelan Transportasi, Institut Teknologi Bandung, BandungKhisty, C.J. and Lall, B.K., 2005. DasarDasar Rekayasa Transportasi. Jilid 1. Edisi Ketiga. Erlangga. Jakarta. 